\title{
SESSENTA ANOS DE TELENOVELA NO BRASIL: UM OLHAR CULTURAL E CRÍTICO
}

\author{
SIXTY YEARS OF SIT COMS (TELENOVELA) IN BRAZIL: A CULTURAL AND \\ CRITICAL LOOK
}

SESENTA AÑOS DE TELESERIES (TELENOVELA) EN BRASIL: UNA MIRADA CULTURAL Y CRÍTICA

\author{
Roberto Ramos \\ PUCRS \\ rr@pucrs.br
}

\section{Resumo}

A Telenovela está completando seis décadas no Brasil. É o principal gênero da Televisão nacional. Surgiu, em 1951, na TV Tupi, mas se afirmou na Rede Globo, como programa massivo. Transformou-se em produto de exportação, devido à sua importância. Pode ser estudada, com diferentes olhares. Neste ensaio, iremos contemplar os seus aspectos culturais. Para tanto, disponibilizaremos os pressupostos teóricos, sobretudo, de Roland Barthes, de Theodor Adorno e Max Horkheimer, com uma abordagem cultural e crítica.

Palavras-chave: Telenovela; Cultura; Indústria Cultural.

\begin{abstract}
The Telenovela is celebrating six decades in Brazil. It is the main genre of national TV. Appeared in 1951 in the TV Tupi, but said on Globo, as massive program. He became an export product, due to its importance. Can be studied with different looks. In this essay, we will consider its cultural aspects. To do so, we will provide the theoretical assumptions, above all, Roland Barthes, Theodor Adorno and Max Horkheimer, with a critical and cultural approach.
\end{abstract}

Keywords: Telenovela; Culture; Cultural Industry.

\section{Resumen}

La telenovela completa seis décadas en Brasil. Es el principal género de la televisión nacional. Surgida en 1951 en la TV Tupi, se ha firmado en la Red Globo como programa masivo. Se ha transformado en producto de exportación devido a su importancia. Ella puede ser estudiada bajo 
distintas miradas. En ese artículo iremos contemplar los aspectos culturales. Para tanto, disponibilizaremos los presupuestos teóricos de Roland Barthes, de Theodor Adorno y de Max Horkheimer sobretodo en tanto que abordaje cultural y crítica.

Palabras clave: Telenovela, Cultura, Lenguaje.

\section{Introdução}

A Telenovela, no Brasil, parece ter um sentido especial. É o programa, que melhor sintetiza a produção televisiva nacional. Possui uma grande influência cultural, em um país, marcado e demarcado por tantas diversidades regionais, com uma geografia continental. Significa uma das principais representações sociais da realidade brasileira.

No presente ensaio, contemplaremos as seis décadas da existência do gênero. Explicitaremos as Telenovelas, que foram mais representativas das diferentes épocas históricas, considerando as suas questões culturais. Iremos referir o pioneirismo de Sua Vida me pertence e as inovações de Beto Rockfeller, ambas da TV Tupi. As demais serão da Globo, devido à sua importância na produção e na exportação, bem como o seu formato de singularizar os folhetins eletrônicos. Priorizaremos uma abordagem cultural e crítica, através, sobretudo, dos pressupostos teóricos de Roland Barthes, Theodor Adorno e Max Horkheimer.

A TV Globo foi inaugurada em 26 de abril de 1965. Antes, em 1962, assinou um contrato com o grupo norte-americano Time-Life, que se estendeu até 1969. Recebeu 5 milhões de dólares na transação. Descumpriu o artigo 160, da Constituição vigente, que, na época, proibia a presença de capital estrangeiro em Mídia, que fosse fruto de concessão estatal.

O ilícito foi comprovado por uma Comissão Parlamentar de Inquérito (CPI) no Congresso Nacional. Os militares, que chegaram ao Poder, em 1964, e se perpetuaram até 1985, não tiveram maiores dificuldades. Resolveram o impasse. Desconsideraram o texto constitucional. Bastou uma assinatura do então presidente, Costa e Silva, e todos ficaram bem. Foi legalizada a situação da Globo. 
Os militares optaram pelo modelo neocolonial da Atualização Histórica. Internacionalizaram o mercado interno. Implantaram uma modernização tecnológica à custa de empréstimos, contraídos junto ao capital estrangeiro. $\mathrm{O}$ aparente progresso foi alcançado, com o pecado original da dependência.

Sem apoio popular, a Ditadura Militar necessitava de uma grande Mídia, para promover a integração nacional, bem como a sua legitimação. A TV Globo assumiu este papel de vender, aos brasileiros, a certeza de que tudo estava muito bem, às mil maravilhas. Não poderia ser melhor.

Mais do que a dimensão quantitativa (5 milhões de dólares) a emissora se apropriou do modelo televisivo da Time-Life. Instalou a sua Central de produção no Rio de Janeiro, em uma cidade, com importância histórica e cultural, para o país. Assumiu, ainda, outras duas teses norteamericanas, vigentes na época. Desenhou-se, como uma rede de Televisão mista, tendo as suas próprias concessões e com emissoras afiliadas. Tal perspectiva visava a ter autonomia de substituir canais, em caso de perda de algum, sem ter, que, neste particular, comer pelas mãos do Estado.

A terceira tese observava a necessidade de ter um telejornal, antecedido e sucedido por programas de grande audiência. Foi o que fez a Globo. Em 1970, conseguiu 80 pontos de audiência, com a telenovela Irmãos Coragem. Cercou o Jornal Nacional (JN), com Telenovelas, constituindo o seu horário-nobre, que persiste até hoje.

O então diretor-presidente da Globo, Roberto Marinho (1988, p. 17), hoje, falecido, explicava a liderança, por intermédio da "competência":

A posição hegemônica, alcançada pela Rede Globo, foi obtida em função de ela ser uma empresa, que se preocupou com planejamentos, investimentos e orçamentos a longo prazo. Optou por uma administração profissional e não pessoal, não preocupada com o aqui e agora. Essa hegemonia não foi consentida: foi conquistada por uma empresa em que o dono reinvestiu 100\% dos lucros durante 14 anos. A opção de produzir (internamente) a maior parte de nossa programação, ainda que mais cara, parece ter sido correta: é só conferir os índices de audiência da Globo (...)

\section{AIMUS Revista Interamericana de Comunicação Midiática}


A Rede Globo de Televisão transformou-se em uma grande exportadora de Telenovelas. "Exporta para mais de 130 países, sendo que 100 deles exibem anualmente algum título da emissora, os maiores clientes são os países da Europa e Oriente Médio, consumindo $74,2 \%$,seguido por América Latina com 13,5\%, América do Norte com 9,5\% e Ásia com 2,4\%.20 No catálogo da emissora estão mais de 280 novelas e 60 minisséries” (Valentim, 2007, p. 16).

A Cultura, conforme Barthes (Ibidem, s.d., p. 84), é o " conjunto infinito das leituras, das conversas - ainda que sob a forma de fragmentos prematuros e mal compreendidos --, em resumo, o Intertexto, que faz pressão sobre um trabalho e bate à porta, para entrar”. O Intertexto é "o banco das influências, das fontes, das origens", sublinha Barthes (Ibidem, p. 94). Representa o grande conjunto de influências textuais, que abrigamos, explicita e implicitamente, em nossos textos, consciente e inconscientemente.

O próprio Barthes (Ibidem, p. 84-85) revela algumas de suas influências. "Para citar nomes, diria, pelo que me concerne, que o impulso semiológico vem de Saussure, lido em 1956. Devo muito às conversas que tive, desde 1950, com Greimas, que me fez conhecer muito cedo a teoria jakobsoniana dos 'shifters' e o alcance formal de certas figuras, como a metáfora, a metonímia, a catálise e a elipse. Hjelmslev permitiu-me desenvolver o esquema da conotação, noção, que teve sempre uma enorme importância para mim”.

A Cultura, pelo olhar barthesiano, está relacionada às práticas linguageiras. É um dos recursos básicos, para a capacidade de refletir, de ser e de viver, sendo constituinte e constituída pela produção das subjetividades humanas. Sintetiza o grande conjunto de fontes, que, implícita e explicitamente, alimenta os nossos textos.

Sobre a Cultura massiva, o semiólogo desenvolveu uma abordagem crítica. "A forma bastarda da cultura de massa é a repetição vergonhosa: repetem-se os conteúdos, os esquemas ideológicos, a obliteração das contradições, mas, se variam as formas superficiais; há sempre livros, emissões, filmes novos, ocorrências diversas, mas é sempre o mesmo sentido (Ibdem, 1995, p. 51).

A urbanização, a tecnologia e a evolução do modo de produção capitalista proporcionaram o surgimento da Indústria Cultural. Os modos de ser, pensar e viver começaram 
a ser codificados e decodificados dentro da estrutura da produção, da circulação e do consumo. Transformaram-se em mercadorias.

Adorno e Horkheimer (1987) observaram a designação de Indústria Cultural, como a mais apropriada. A nomeação Cultura de Massa já é, a priori, mentirosa. Exporta um estelionato verbal. Não se inspira e nem se origina dos valores, autenticamente, populares. Representa a adaptação e a padronização da Cultura, como Intertexto, da elite, para o consumo massificado. É mais uma mercadoria na vitrine do mercado.

Os autores (Ibidem, p. 113-135) salientam o comprometimento da Indústria Cultural com a "produção, circulação e o consumo". É o trinoômio tradicional de qualquer empresa, mas com uma singularidade. Possuem uma mercadoria diferenciada. É a Cultura, reificada pela lógica do lucro a qualquer preço. Eles evidenciam:

(...) O Cinema, o Rádio, Televisão e as Revistas constituem um sistema. Cada setor é coerente em si mesmo e todos os são em conjunto 9...) A racionalidadade técnica é a racionalidade da dominação (...) A atitude do público, que, pretensamente e de fato, favorece o sistema da Indústria Cultural é uma parte do sistema, não a sua desculpa (...) A diferença dos produtos sempre revela a mesma coisa. Perpetua a ilusão da concorrência e das possibilidades de escolha (...)

Não vamos montar o histórico da Telenovela, principal produto da Indústria Cultural brasileira.. Apenas juntaremos elementos, que possam dar uma visão genérica sobre o assunto. Qualquer outra preocupação cronológica pode ser catalogada como descartável para a proposta do nosso estudo. Cabe-nos considerar os seus aspectos culturais complexos, que envolvem a sua unidade e a sua diversidade.

Nos seus primeiros passos, a Televisão foi guiada pelos programas e seus profissionais consagrados no Rádio. A TV Tupi transmitiu a primeira Telenovela, Sua vida me pertence, em 1951, que, anteriormente, tivera êxito radiofônico. Walter Forster fazia o papel principal. Cada capítulo durava 15 minutos e a história, três meses (Bueno, 1983. p. 18).

As multinacionais e as importações marcaram a migração das radionovelas, para os estúdios televisivos: "É interessante verificar que o modelo inicial da novela brasileira foi trazido 
pela Colgate-Palmolive, já que a multinacional experimentara o gênero com sucesso em outros países da América Latina” (Caparelli, 1982, p. 136).

Os folhetins, no século XIX, e as novelas, no XX, têm papéis análogos, de acordo com Caparelli: "Os folhetins apareceram numa época em que a imprensa necessitava de leitores, e a oferta de um produto, como o folhetim, veio suprir essa necessidade, pois a uma maior tiragem correspondia uma queda no preço do exemplar vendido. No Brasil, a novela aparece de uma maneira mais sistemática na segunda fase da televisão no País, quando esse meio de comunicação está em busca de audiência” (idem, p.136-137).

Houve, na Primeira Fase da Televisão brasileira, uma característica essencial. Nutriu-se da improvisação. Não foi planejada. Deu-se pela iniciativa do empresário Assis Chateaubriand, comprando os equipamentos nos Estados Unidos e inaugurando a TV Tupi, de São Paulo. Não existia, ainda, uma demanda das relações capitalistas de produção, que apontasse a necessidade da implantação do novo meio. Para viabilizá-lo, ocorreu a busca de programas e comunicadores radiofônicos, para a sua viabilização mercadológica, em termos de público e de audiência.

O original do cubano, Félix Caignet, O Direito de Nascer, escrita em 1946, identifica a fase de importação e influência radiofônica,. Ela faz sucesso, primeiramente, na Rádio Nacional do Rio de Janeiro. Ficou um ano e nove meses no ar em 1951-52. Depois, Esteve em vídeos da Rede Tupi de São Paulo, e na TV Rio, com estréia em 7 de dezembro de 1964. Voltou à Tupi, em 1978, com a adaptação de Teixeira Filho.

A autora cubana Glória Magadan dirigiu os Departamentos de Teledramaturgia da Globo e da Tupi. Ela adorava romances monárquicos, por onde rainhas e princesas caminhavam. Não acreditava em temas nacionais. Nessa fase de importação, o enredo era unidimensional. Abordava um tema e tudo gravitava em torno dele. Os personagens impostavam a voz e davam um tom de comunicado oficial às falas.

Magadan criou Anastácia, a mulher sem destino, em 1967, na Globo, com Leila Diniz no papel principal. Ela era uma princesa, perdida na Rússia. A cubana defendia a tese de tanto mais longe do Brasil, melhor. Por isso, perseguia lugares e tempos distantes, sem muito êxito. Ela 
entregou um enredo, com 40 personagens, gastos fantásticos e uma audiência quase abstrata de Anastácia, para Janete Clair:

“(...) E Janete, depois de uma noite sem dormir, encontrou a solução. Colocou um terremoto no script, que matou 35 personagens supérfluos. Os cinco sobreviventes levaram o drama até o final, com menos gastos para a emissora" (Rito, 1973, p. 3).

A grande inovação do gênero ocorreu, porém, com a falecida Tupi, dos já sepultados Diários e Emissoras Associados. Ela apresentou Beto Rockfeller, de Bráulio Pedroso, no final da década de 60. Nacionalizou e urbanizou a temática, ambientada no concreto de São Paulo, com diálogos coloquiais. Beto, Luis Gustavo, era o anti-herói, um malandro paulista, que fingia ser milionário, para dar o seu golpe do baú. O elenco foi de primeira. Teve Walter Forster, Jofre Soares, Irene Ravache, Plínio Marcos, Beth Mendes, Maria Dalla Costa e Débora Duarte, entre outros.

O primeiro grande sucesso nacional da Globo foi Irmãos Coragem, de Janete Clair, em 1970-71, fruto da consolidação da rede. Com Glória Menezes e Tarcísio Meira, expunha o coronelismo interiorano e possuía uma abertura para o futebol, uma das armas ideológicas da Ditadura, de Emílio Garrastazu Médici. Instaurou a supremacia da emissora sobre os concorrentes, garantindo audiência no horário das oito. Foi a nascente do padrão global.

O Ibope - Instituto Brasileiro de Opinião Pública e Estatística - faz a avaliação da audiência dos programas. Os seus números e técnicas são duvidosos. Todavia, servem, ainda que precariamente, para calcular sucessos e fracassos da televisão. A autora Janete Clair, já falecida, obteve o maior índice de Ibope do País. A façanha aconteceu em Selva de Pedra, 1972-73, às oito, atingindo $100 \%$ em São Paulo e no Rio de Janeiro. O que ninguém mais conseguiu, mesmo com a evolução tecnológica e de linguagem do gênero.

Há novelas que abordam temas conflitantes com os interesses dos clientes do departamento comercial. O Espigão, de Dias Gomes, 1974, e O Grito, de Jorge Andrade, 197576, ambas às dez, trataram de especulação imobiliária. Por isso, sofreram pressão e censuras dos anunciantes da Globo (Carvalho, Ribeiro e Kehl, 1979-80, p. 60). 
Aos poucos, a Televisão aproveitou os clássicos da literatura, adaptando-os para o vídeo. O notável jurista Afonso Arinos de Mello Franco acompanhou Senhora, 1975, às seis, por gostar do estilo de José de Alencar. Ele considerou bons os costumes e os cenários, mas encontrou terríveis equívocos históricos: "Uma personagem falava em saldar dívida com notas promissórias, quando se sabe que este título cambial só surgiu em 1920. Outro dizia que fulana tinha 'it', palavra que só surgiu com o cinema americano nos anos 30. Erros desse tipo podem ser creditados, por certo, ao célebre 'ritmo de TV' de que as emissoras tanto se orgulham e padecem" (Rodrigues, Buchabqui, e Moure , 1978, p. 2).

Marques Melo pesquisou 135 donas-de-casa em dez bairros paulistas: "Para o telespectador, a novela representa uma possibilidade de fugir das amarguras do cotidiano e ir ao encontro de uma vida, cheia de mistério, suspense, amor e prisão, onde tudo acaba bem. Os maus são castigados; os bons, recompensados. Isto ocasiona um tipo de fenômeno psicológico chamado de 'satisfação substitutiva'... Assistindo aos capítulos das novelas, as pessoas esquecem seus verdadeiros problemas" (Beltrán e Cardona, 1982, p. 81).

O crescente abrasileiramento de gênero provocou modificações nos enredos. Eles abandonaram a abordagem de apenas um tema, uma das características dos dramalhões da década de 60. Tornaram-se multidimensionais, isto é, desenvolvendo temas e subtemas. De um folhetim eletrônico para outro, parece que tudo muda. Enredos, personagens, ambientes, aparentemente, se diversificam. Deixam a impressão de que cada um constitui um universo à parte, autônomo do outro. Não é assim.

Isso dialogou com um momento histórico específico. A Ditadura Militar, que usurpou o Poder, em 31 de março de 1964, procurou se legitimar, através da Televisão, para tanto investiu, econômica e tecnologicamente. Criou a Embratel - Empresa Brasileira de Telecomunicação --, em 1967, que filiou o país ao Consórcio Intelsat, dos Estados Unidos. O que viabilizou a massificação televisiva, em dimensão nacional. Aconteceu a Segunda Fase da Televisão brasileira, marcada e demarcada pela Massificação, convivendo com o "Milagre Brasileiro", o crescimento do país, às custas do endividamento externo e de obras faraônicas. 


\section{Cultura Zona Sul}

Qualquer telespectador pode chegar facilmente a uma constatação. A realidade das telenovelas é bem mais bela que a da minha rua, a da minha cidade, enfim, a do meu país. Os ricos adormecem em suas mordomias e os pobres não são tão miseráveis. É a Cultura da Zona Sul, do Rio de Janeiro, que parece, sobretudo, se sintetizar em Copacabana, Leme, Arpoador, Ipanema e Leblon. Tece uma perspectiva cultural, própria do Capitalismo de uma elite carioca. Mesmo que o ambiente geográfico possa ser outro, a sua hegemonia parece permanecer.

Os enredos se movem em torno de elites em qualquer geografia e conjuntura. A realidade se estrutura pela vida dos ricos. Eles moram em mansões e apartamentos de cobertura e os seus meios de produção estreitam fantasiosamente a convivência com os pobres. Os valores culturais e econômicos estão concebidos dentro do universo da Zona Sul carioca, especialmente.

Os Ossos do Barão, de Jorge Andrade, 1973-74, às dez, com criatividade testemunhou a cosmovisão elitista. Traçou o conflito entre a aristocracia e a burguesia numa disputa hegemônica, desta vez em São Paulo. Também, os latifundiários foram bem tratados em $A$ Sucessora, de Manoel Carlos, 1978-79, às seis. Marina, Suzana Vieira, digna descendente de uma família de fazendeiros, casou com o milionário Roberto, Rubens de Falco (Romântica, n. 259, 1978:12). O enredo girava em torno do casal.

Os donos de uma sofisticada empresa de jóias enfeitavam a história de Brilhante, 198182, às oito. Era o casal Chica, Fernanda Montenegro, e Vitor, Mário Lago. Havia a preocupação com a sucessão da fábrica. Em Final Feliz, de Ivani Ribeiro, 1982-83, às sete, retratou gente de dinheiro, outra vez. A trama era prodigiosa. A família pernambucana Villela, proprietária de uma usina de açúcar, mudou para o Rio de Janeiro. Não Faltaram relações amorosas adocicadas.

Os novos ricos são os mais requisitados. Eles desenvolvem a mística de que quem trabalha e se esforça vence na vida. Insinuam a perspectiva de que todos possuem condições iguais de ascensão social. Nonô Correa, Ary Fontoura, foi um deles e Amor com amor se paga, de Ivani Ribeiro, 1984, às seis. Na sua juventude, chegou a roubar, para comer. Contudo, enriqueceu e virou dono de quase todos os imóveis da cidade. 
Há a demonstração mágica da ascensão social. Do dia para a noite, os pobres se transformam em ricos. Isso não é tudo. Aí, levanta-se a parábola do milionário infeliz, construída por diferentes estratégias humanas. O enriquecimento de Nonô levou-o à absolutização do dinheiro. Tinha um quarto secreto, onde guardava dólares, ouro, jóias, enfim o seu tesouro. No entanto, vivia atormentado. A fortuna era contraproducente. Impunha-lhe o desconforto do receio de ficar pobre, de ser assaltado e de se tornar vítima de interesseiros. Nutria a psicologia do pânico.

Pai Herói, de Janete Clair, em 1979, ocupava o horário das oito. A imagem mostrava os bairros da Zona Sul carioca. Os seus moradores estavam confortavelmente instalados. O capital jorrava pelas torneiras de suas empresas. Apesar de pertencer a esse mundo da fantasia minoritária, Carina, Elizabeth Savalla, possuía um déficit afetivo. O casamento não a fizera feliz. Sentia-se mal-amada. Não sabia o que queria da vida. Hesitava entre as colunas sociais e o retorno ao palco como bailarina.

A ambientação Zona Sul é um cartão postal do nosso status quo. Ilustra o mundo harmonizado, que se edificou às custas das paisagens marginalizadas. Acena com a expectativa de que podemos ter um passaporte, via livre iniciativa, para lá. Basta aderirmos a esse cartão postal de autêntico e legítimo jardim do Éden social e cultural.

Claro que o dinheiro não deposita, automaticamente, felicidade na conta corrente de ninguém. Todavia, o capitalismo nos empurra para a produção e para a competição, prometendo uma suposta ascensão social. Ao mesmo tempo, para resguardar os privilégios, os dilui, afirmando que não são definitivos para a felicidade. Aí, flagra-se a contradição.

A herança é um ingrediente considerável em qualquer trama. Nesse contexto, em que o novo rico é tão destacado, ela expressa uma simbologia apreciável. Representa a transmissão de direitos ao capital, legitimamente obtido. Insinua que os seus detentores trabalharam para isso. Logo aparece a lógica de que os filhos, parentes e até amigos devem compartilhar dos benefícios hereditários.

Terminou em assassinato em Água Viva, de Gilberto Braga, 1980, às oito. Cléber, José Lewgoy, matou o seu filho adotivo Miguel, Raul Cortez, pois este descobrira o seu roubo em 
parte de sua herança. Apelou para o revólver para definir a situação. Havia, também, uma grandiosa herança em Jogo da Vida, de Silvio de Abreu, 1981-82, às sete. Somava 1 milhão de dólares. Estavam bem escondidos, colocados numa estátua, que compunha um quarteto de cupidos. Era uma quantia digna de virar a cabeça do mais estóico personagem.

A inflação brasileira foi responsável pelo reajuste nos valores das heranças. Um Sonho a mais, de Lauro César Muniz, Daniel Más, Mário Prata, 1985, às sete, lidava com 1 bilhão de dólares. Todo esse dinheiro pertencia ao Volpone, Ney Latorraca. Todavia ele era acusado de ter assassinado o sogro. Por isso, fugira para o exterior e regressara ao Rio para provar a sua inocência.

Amante, também, fatura alto. Foi o que aconteceu com Verona, Cássia Kiss, em Livre para voar, de Walter Negrão, 1984-85, às seis. Ela teve um romance com o seu patrão, o empresário J.J., Jorge Dória, que faleceu. No seu testamento, deixou 20\% das ações da fábrica para a jovem.

Estela, Tônia Carrero, não tinha preocupações com a sua residência em Água Viva, de Gilberto Braga, 1980, às oito. O ar-condicionado the proporcionava o seu clima predileto. Morava num lindo apartamento na Zona Sul carioca, decorado por acrílicos e araras de verdade. Miguel, Raul Cortez, cirurgião plástico, e Estela eram sócios em uma clínica badaladíssima no Rio. Ele possuía, entre outras propriedades, um iate e uma ilha em Angra dos Reis. Gente finíssima, digno representante da elite.

Em gosto pela natureza, o bicheiro Célio, também Raul Cortez, era imbatível. O seu endereço se situava na Zona Norte, precisamente no Encantado, em Partido Alto, de Glória Peres e Agnaldo Silva. No interior de sua casa havia até um pavão autêntico na sala de estar.

A sofisticação ganhou notoriedade em Transas e Caretas de Lauro César Muniz, 1984, às sete. Ela apresentou dois estilos de morar distintos, marcando as características psicológicas dos personagens. Eles eram dois irmãos: Jordão, Reginaldo Faria, e Thiago, José Wilker. A casa de Jordão mantinha de pé a fachada conservadora, discreta. Estátuas e obras de arte modelavam o requinte de seu visual. Refletia a personalidade de seu dono, aristocrático leiloeiro de peças artísticas. Cultivava a música clássica, arranhando um violino. 
O apartamento de cobertura de Thiago poderia ser chamado de futurista. Culminava com uma piscina. Possuía um barzinho e cama giratórios, câmeras de TV, computadores, vídeocassetes e até um robô, O Alcides. Havia dois conceitos em jogo. O careta identificava Jordão e transas, Thiago. Ambos eram burgueses, porém com consequências distintas. Eles estavam sintetizados no presente. Dimensionavam, respectivamente, o passado e o futuro. No entanto, eram roupagens temporais instaladas na cosmovisão burguesa. Embalada pelo jeito de ser da Zona Sul carioca.

No decorrer da história, Jordão e Thiago chegaram a trocar de residências para configurar as alterações de suas personalidades. Mesmo assim, qualquer possibilidade de transformação se estreitava nas fronteiras burguesas. Exprimia o slogan positivista de que tudo já está delineado e funciona em si mesmo no raciocínio elitista.

Uma das mais lindas casas novelescas estava em A Gata comeu, de Ivani Ribeiro, 1985, às seis. Pertencia ao empresário de turismo Horácio, Mauro Mendonça. Estava localizada em Angra dos Reis. Dispunha de uma piscina e se cercava de praia por todos os lados.

Uma fonte luminosa dava requinte em Vereda Tropical, de Carlos Lombardi e Silvio de Abreu, 1984-85, às sete. Ela conferia nobreza à mansão de Oliva, Walmor Chagas, um novo rico. O pátio era todo gramado, sacralizado por uma piscina ao centro.

A abolição das divisórias ocorreu em Corpo a Corpo, de Gilberto Braga, 1984-85, às oito. A mansão do publicitário Zeca, Caíque Ferreira, não apresentava divisões internas. Era compacta e ampla. Nos seus fundos, abria espaço para uma piscina, delimitada por plantas.

Fizemos descrições de aspectos das residências de personagens. Apartamentos de cobertura, até com robô, outro, com araras verdadeiras a acrílicos, apareceram. Mansões em Angra dos |Reis, e uma fonte luminosa, surgiram. Na Zona Norte, a casinha do bicheiro Célio mostrava um pavão verdadeiro na sala de estar. São ambientes e posses, definitivamente, da classe dominante.

Observamos o significado da burguesia. O novo rico tem um papel bastante especial. Garante a ascensão e a justiça social, através da livre iniciativa. Sai do nada e se transforma em empresário. Exporta a mística de que quem trabalha vence. A partir daí, o direito de herança 
adquire legitimidade. No entanto, sabemos que não é bem assim. Só o trabalho não é o suficiente. Há a necessidade de explorar o dos outros, para ascender do nada à condição de novo rico.

De uma maneira geral, os pobres podiam ser contados em Livre para Voar, de Walter Negrão, 1984-85, às seis. O maquinista Pedrão, Elias Gleiser, era um deles. Residia na periferia de Poços de Caldas, interior de Minas Gerais, mas possuía telefono na sua casinha modesta. Os seus filhos apresentavam atividades diversas. Quim, Thiago Santiago, não trabalhava. Inicialmente, Julinha, Thaís de Campos, era copeira na fábrica de Jajá, Rodolfo Bottino, mecânico e sócio da lancheria.

Os pobres eram representados pelas funcionárias da cristaleria. Verona, Cássia Kiss, Tuca, Élida L’Astorina, Suzana, Débora Fucs, Janda, Denise Milfont, e Rô, Cássia Fourreaux, todas viviam na República. Ao lado delas, estavam Pardal, Tony Ramos, um escultor andarilho, e seu amigo, o pívete e órfão Gibi, Fernando Almeida. Ainda, existia Edu, Cássio Gabus Mendes.

A plebe se relaciona, intimamente, com os patrões. Julinha fez amizade com a dona da fábrica de cristais, Bebel, Carla Camuratti, e esta usou de disfarce. Ela se fez de Cristina, a garota do café, para melhor conhecer os seus funcionários, até parece conto de fadas ou algo parecido. Por aí, começou a ascensão de Julinha. Mais tarde, ela ganhou uma loja de cristais da patroa. Bebel acabou com Cristina a assumiu a cristaleria. No auge da recessão econômica da fábrica, ela promoveu a copeira em proprietária, em gesto mágico e generoso.

O casamento resolveu o problema financeiro de muita gente. Redistribuiu a renda e as propriedades. Representou uma revolução privada, permitida pelo capitalismo, pois o preserva. Conduz para a passividade acrítica. Os noivos, ao pronunciarem o sim, indiretamente se comprometem com o modo de produção. Assumem a responsabilidade de reproduzi-lo, através dos filhos. Nas novelas, é um fator de justiça social.

Pedrão casou com a dama de companhia de Bebel, a professora portuguesa, Carolina, Laura Cardoso, Jajá fez o mesmo com Janda. O burguesinho Alvinho, João Carlos Barroso, 
ficou com Tuca. Álvaro, Edney Giovenazzi, acionista da cristaleria, se uniu a Verona. Os casamentos se sucederam, bem ao gosto de uma maratona.

Julinha casou com Edu e presenteou a sua loja, para a cunhada Janda. Ele subiu na vida, com a ascensão de sua mãe Heloísa, Suzana Saldanha, que se amparou num milionário. Ela era uma simples costureira, mas acabou esnobando numa Mercedes vermelha, com chofer e tudo. Virou dama da sociedade de Belo horizonte. Desfrutou as delícias das maiores mordomias, com asa contas bancárias do marido, um dono de haras.

Tais telenovelas possuíam um contexto. As contradições sociais se avolumaram. A Ditadura Militar não conseguiu conter as crises econômicas. Os artifícios do "Milagre Brasileiro", que deram tão certo na década de 60, agora, se submeteram ao apartheid social, em que a economia de mercado criou entre pobres e ricos.

A TV Tupi faliu e o seu espólio foi dividido. Surgiram duas novas redes: a Manchete, cujo espólio se tornou RedeTV, e o SBT - Sistema Brasileiro de Televisão. É a III Fase da Televisão - a da Configuração das novas redes.

Em 1990, a Rainha da Sucata, de Silvio de Abreu, às 20h30min, trouxe Maria do Carmo (Regina Duarte), que “enriquece com os negócios do pai, Onofre (Lima Duarte), vendedor de ferro-velho, porém mante'm hábitos de seu passado humilde e mora com o pai e a mãe, Neiva (Nicette Bruno), no Bairro de Santana, na Zona Norte de São Paulo. Apaixonada por Edu Figueroa (Tony Ramos), que a humilhara na juventude, ela propõe casar-se com ele, para ajudar a sua família de origem tradicional, mas à beira da falência” (S.A., 2010, p. 150).

A madrasta de $E d u$, a empresária, Laurinha (Glória Menezes) persegue Maria do Carmo, por ser obcecada pelo enteado. Os seus negócios começam a fracassar, "por culpa do administrador Renato Maia (Daniel Filho), em quem ela confiava plenamente. Ele, na realidade, é um incorrigível corrupto, que aplica um golpe em Maria do Carmo".

Laurinha se suicida tenta incriminar Maria do Carmo, que se livra da acusação e da pobreza. Reabilita as suas finanças, resgatando o ferro-velho. Reconcilia-se com Edu. Tudo acaba bem, em ritmo de final feliz, bem ao gosto da linearidade do maniqueísmo. Os maus são punidos e os bons recompensados pela plenitude da felicidade. 
O Clone, de Glória Perez, em 2001, às 20h30min, comprometeu-se com as questões científicas, contracenando com as dificuldades um amor quase impossível entre Jade (Giovanna Antonelli) e Lucas (Murilo Benício). O cientista Augusto Albieri (Juca de Oliveira) cria um clone do seu afilhado, falecido, Diogo (também, vivido por Murilo Benício).

Os ambientes se dividiam entre o Marrocos e o Rio de Janeiro, sobretudo, através dos Bairros de São Cristóvão e Copacabana. Apesar das diversidades aparentes, havia uma unidade. Era a hegemonia da Cultura Zona Sul, cultivando os hábitos dos ricos e da classe média cariocas, interagindo com a pobreza de São Cristóvão, pelos laços do amor entre os personagens.

As duas famílias muçulmanas, do Marrocos, eram lideradas por "tios", Ali (Stênio Garcia) e Abdo (Sebastião Vasconcelos), Ambos eram metonímias da elite local. Encontravamse ambientadas em famílias ricas. A família de Abdo, mais especificamente, o seu sobrinho Said (Dalton Vigh), no curso do enredo, se tornou um empresário multinacional, sem um fato concreto e sem nenhuma causa compatível.

Com a eleição de Fernando Collor de Melo, em 1989, à Presidência da República, resgatando a Democracia, via voto direto, aconteceram repercussões políticas, sociais e culturais. Houve o surgimento da TV por Assinatura, que trouxe consequências nos canais abertos. As Telenovelas, da Globo, buscaram novos mercados internacionais, como foi o caso de $O$ Clone, investindo no mundo árabe. Assim sendo, se materializou a IV Fase de Segmentação e Globalização, que singulariza a contemporaneidade da Televisão brasileira.

Ao mesmo tempo, acompanhamos fatos curiosos nos folhetins eletrônicos. Não existem grandes distâncias entre as classes sociais. Explorados e exploradores convivem fraternalmente. A ascensão social ocorre, magicamente, através do casamento que parece funcionar como grande fator do equilíbrio social. Parece ser o principal fator de distribuição de renda.

Presenciamos a Cultura Zona Sul conviver com os pobres. Não existem impedimentos. A luta de classes se transforma ficcionalmente. Os pobres e os ricos mantêm uma relação íntima, que permite o casamento. Ele permite a revolução privada, distribuindo renda, propriedades e meios de produção para os cônjuges. A facilidade da ascensão social promove a competição entre os personagens e, indiretamente, entre os telespectadores. 


\section{Modismos Culturais}

A telenovela proporcionou a alteração de inúmeros hábitos e a adesão a outros modismos na vida dos brasileiros. A sua estrutura de acompanhamento em capítulos diários colaborou, para alterar a paisagem das relações e interações humanas. Parece ser a passarela ideal, para a moda. Por ela, desfilam novas opções de vida. Mexa-se. Não pense nada. Curta. Faça isso e aquilo. Embarque em qualquer passatempo. A classe dominante resolve todos os problemas, para você.

Para organizar as nossas vidas, a Globo não se preocupa com os gastos. Abriu as portas do Club 17, em Dancin'Days, de Gilberto Braga, 1978-79, às oito. Importou o gosto norteamericano pelas discotecas e o lançou no Brasil. $\mathrm{O}$ " 17 ” era tão sofisticado quanto às discotecas reais. Consagrou o cantor John Travolta, dos Estados Unidos. Fez muito sucesso nas costas do folhetim eletrônico. Como produto da indústria cultural, foi instantâneo e meteórico. Entretanto, Dancin ficou com a pose de ter lançado as discotecas.

Em 2010, Araguaia,de Walter Negrão, às seis, vendeu dois modismos básicos. Empenhou-se em compartilhar cenas, para massificar as possibilidades turísticas da cidade. O próprio enredo estava comprometido em compartilhar cenas sobre as belezas naturais. Apresentava uma agência de turismo, de propriedade do personagem, Fred, vivido por Rafael Viana, que dava emprego, para vários outros personagens.

Também, houve a tentativa de reescrever a história da Guerrilha do Araguaia, reprimida durante a Ditadura Militar, com a anuência legitimadora da Globo. Agora, o enredo, em seu maniqueísmo, tornava os guerrilheiros em autênticos heróis e os agentes de repressão em explícitos vilões. Ambos eram órfãos de causas mais específicas. Não tinham motivações sociais mais consequentes.

A emissora, entretanto, tinha razões bem determinadas. A presidenta da República, Dilma Roussef, eleita em 2010, foi guerrilheira nos seus tempos de juventude. Por isso, afirmar a importância da luta armada era significante. Tornou-se um imperativo, para agradar e ter a simpatia dos novos detentores do Poder. A lógica oficialista foi mantida, com zelo, nos períodos da Ditadura Militar e da Democracia. 
Alguns modismos, ditados pelas Telenovelas, são bastante insistentes. Passam de uma para a outra. Não entendemos que a opinião pública seja passiva. Entretanto, fechar os olhos, para a influência dos modismos dos folhetins eletrônicos pode representar omissão e cumplicidade, comprometidas com a legitimação cega das mensagens, ditadas pela padronização e repetições da Indústria Cultural.

A Cultura Zona Sul parece absorver um significado duplo. É responsável pela integração do sujeito na sociedade e no consumo, de modo consensual. Para isso, servem os paradigmas de viver e pensar ao gosto da elite carioca. Os enredos das telenovelas trocam nomes, personagens e cenas. No entanto, são sempre os mesmos. Contam a historia da adaptação social. O telespectador, ao acompanhar mais um capítulo, está sendo administrado, para a reprodução do Capitalismo. A Infraestrutura, o econômico, e a Superestrutura, o cultural, são faces da mesma moeda. Estão colados pela Ideologia, como negócio comercial e massivo, de acordo com Adorno e Horkheimer.

\section{Referências}

ADORNO, Theodor e HORKHEIMER, Max. Dialética do Esclarecimento - fragmentos filosóficos. Rio de Janeiro: Jorge Zahar, 1987.

BARTHES, Roland. Escritores, Intelectuais, Professores e outros ensaios. Lisboa: Presença, s. d..

. O Prazer do Texto. São Paulo: Perspectiva, 1995.

BELTRÁN, Luis Ramiro e CARDONA, Elizabeth Fox. Comunicação Dominada - OS Estados Unidos e os Meios de Comunicação na América Latina. São Paulo: Paz e Terra, 1982.

BUENO, Zith. A Televisão no Brasil: seu desenvolvimento e Poder. Porto Alegre: PUCRS, Famecos, Curso de Pós-Graduação em Comunicação Social, 1983.

CAPARELLI, Sérgio. Televisão e Capitalismo no Brasil. Porto Alegre: L\&PM, 1981.

CARVALHO, Elisabeth, RIBEIRO, Santusa Neves, KEHL, Maria Rita. TV: Anos 70. São Paulo: Europa, 1979. 
MARINHO, Roberto in MELO, José Marques de. As Telenovelas da Globo - produção e exportação. São Paulo: Summus, 1988.

RITO, Lúcia. A Arte Popular das Novelas. Revista Veja, São Paulo, nº 229, 29 de janeiro de 1973, p. 3.

RAMOS, Roberto. Grã-finos na Globo - Cultura e Merchandising nas novelas. Petrópolis: Vozes, 1986.

RODRIGUES, Áureo José, BUCHABQUI, Margareth e MOURE, Roberto. Polígrafo Telenovela. Porto Alegre: PUCRS, Famecos, Curso de Jornalismo, 1978.

S. A.. Guia Ilustrado TV Globo - Novelas e Minisséries. Rio de Janeiro, Zahar, 2010.

VALENTIM, Aldo Luiz. Internacionalização da Rede Globo: Estudo de Caso da Exportação de Telenovelas. São Paulo: Centro Universitário das Faculdades Metropolitanas Unidas, Trabalho de Conclusão do Curso de Relações Internacionais, 2007.

Original recebido em: $30 / 10 / 2012$

Aceito para publicação em: 03/12/2012

Resumo sobre o autor

Professor Ph.D em Ciências da Comunicação, dos Cursos de Graduação e Pós-Graduação da FAMECOS - PUCRS. Livros publicados: O Âncora e o Neoliberalismo: A Privatização do Sentido, Futebol: Ideologia do Poder, Grã-finos na Globo, Manipulação \& Controle da Opinião Pública, A Máquina Capitalista e A Ideologia da Escolinha do Professor Raimundo. 